\title{
A NEW SPECIES OF STELLILABIUM (ORCHIDACEAE) FROM SOUTHERN COLOMBIA
}

\author{
Marta Kolanowska ${ }^{1}$ \& Ramiro Medina Trejo
}

\begin{abstract}
A new species of Stellilabium Schltr. is described and illustrated based on Colombian material. The novelty is distinguished from the similar S. pogonostalix (Rchb. f.) Garay \& Dunst. and S. alticola Dodson \& Escobar by its ovate lip, which is broadest near the middle. An identification key for the Colombian Stellilabium species is provided.
\end{abstract}

Key words: Andes, biodiversity, Telipogoninae

Marta Kolanowska, Department of Plant Taxonomy and Nature Conservation, The University of Gdańsk, Wita Stwosza 59, 80-308 Gdańsk, Poland; e-mail: martakolanowska@wp.pl

Ramiro Medina Trejo, Sibundoy Valley, Alto Putumayo, Colombia

\section{INTRODUCTION}

The orchid genus Stellilabium Schltr. was described by Rudolf Schlechter (1915) based on S. astroglossum (Rchb. f.) Schltr. The author found that this species differed from other Telipogon Kunth species in its smaller plant size and its flower morphology: elliptic to ovate sepals, denticulate petals, and ovate lip with small lateral lobes. Over ten years later the second species of Stellilabium was described by Ames and Schweinfurth (1925). The relationships between Stellilabium and two other genera later described by Schlechter (1921) Sodiroella Schltr. and Dipterostele Schltr. were discussed by Braas and Lückel (1982a, b), Garay and Romero-González (1998) and Dressler (1999), but currently most authors include Dipterostele and Sodiroella in Stellilabium. Molecular research suggested that all species of Stellilabium should be lumped in Telipogon (Williams et al. 2005), but in our opinion the observable morphological differences between representatives of the two taxa - peduncle and rachis form (flattened in Stellilabium, cylindrical or triquetrous in Telipogon; Dressler 2003) and flower morphology (all tepals similar

\footnotetext{
1 Corresponding author
}

in Stellilabium and dissimilar in Telipogon) - are sufficient to maintain them as separated genera.

Representatives of Stellilabium do not produce pseudobulbs and their stem is short. The small conduplicate leaves are sometimes absent during flowering. The tiny resupinate flowers of Stellilabium are arranged in a lateral, racemose or paniculate, few- to many-flowered inflorescence which is longer than the leaves. The lip is entire or 3-lobed, usually covered with hairs. The gynostemium is short, relatively robust, with a hairy or pubescent column part. Four obovoid to obliquely obovoid pollinia are produced.

About 50 species are currently grouped in Stellilabium. The geographical range of the genus extends from western South America and Venezuela to Costa Rica and Mexico in the north. Species of Stellilabium grow as twig epiphytes, usually in wet cloud forest. Their occurrence has been reported from premontane and montane areas up to $c a 2500 \mathrm{~m}$ a.s.l.

So far 7 representatives of the genus have been reported from Colombia: $S$. alticola Dodson \& Escobar, S. andinum (L. O. Williams) Garay $\&$ Dunst., S. atropupureum P. Ortiz, S. hirtzii Dodson and S. lankesteri (Ames) Dressler (Ortiz 
Valdivieso \& Uribe Vélez 2007; Pérez Escobar et al. 2011; Bernal et al. 2015). The national flora is rather poorly recognized, and in the last few years numerous new species of Orchidaceae have been described from this region (e.g., Kolanowska \& Szlachetko 2014; Hills \& Weber 2012; Dalström \& Ruíz Pérez 2012). In neighboring Ecuador, with a land area four times smaller than Colombia territory, 11 species of Stellilabium have been found (Dodson 2004).

Our research in southern Colombia revealed a distinctive species of Stellilabium, which is described here as new.

\section{TAXONOMIC TREATMENT}

Stellilabium valdiviesoanus Kolan. \& R. Medina Tr., sp. nov.

Figs $1 \& 2$

Species resembling S. pogonostalix (Rchb. f.) Garay \& Dunst. and $S$. alticola distinguished by the ovate lip which is the broadest near the middle.

Holotype: COLOMBIA. Putumayo. Lower part of the village La Cumbre. Alt. 2150 m. 1 Mar. 2014. R. Medina T. 186 (MEDEL).

Plant minute, up to $5 \mathrm{~cm}$ tall. Leaves $1-2 \mathrm{~cm}$ long, $0.3-0.5 \mathrm{~cm}$ wide, oblong-elliptic, acute. Flowers produced singly in succession, yellowish green with bases of petals and lip flushed maroon, veins of petals and lip brownish. Floral bracts up to $2.3 \mathrm{~mm}$ long, ovate, subacute. Ovary $3.5 \mathrm{~mm}$ long. Dorsal sepal $3 \mathrm{~mm}$ long, $1 \mathrm{~mm}$ wide, ovatelanceolate, acute, 1-veined. Petals $3.2 \mathrm{~mm}$ long, $1.3 \mathrm{~mm}$ wide, elliptic, acute, 3-veined, glandular near base. Lateral sepals $2.9 \mathrm{~mm}$ long, $0.9 \mathrm{~mm}$ wide, obliquely lanceolate-ovate, acute, 1-veined. Lip $3 \mathrm{~mm}$ long, $1 \mathrm{~mm}$ wide, ovate, obtuse, with two horn-like appendages at base, 3-veined, base glandular-pubescent, margins minutely ciliate. Gynostemium $0.7 \mathrm{~mm}$ long, with tufts of setose hairs with stellate apices on both anther sides. Capsule $6 \mathrm{~mm}$ long.

Etymology. Dedicated to Pedro Ortiz Valdivieso (1926-2012), an eminent Colombian orchidologist.

Distribution AND ECOlogy. The new species is known so far exclusively from southern
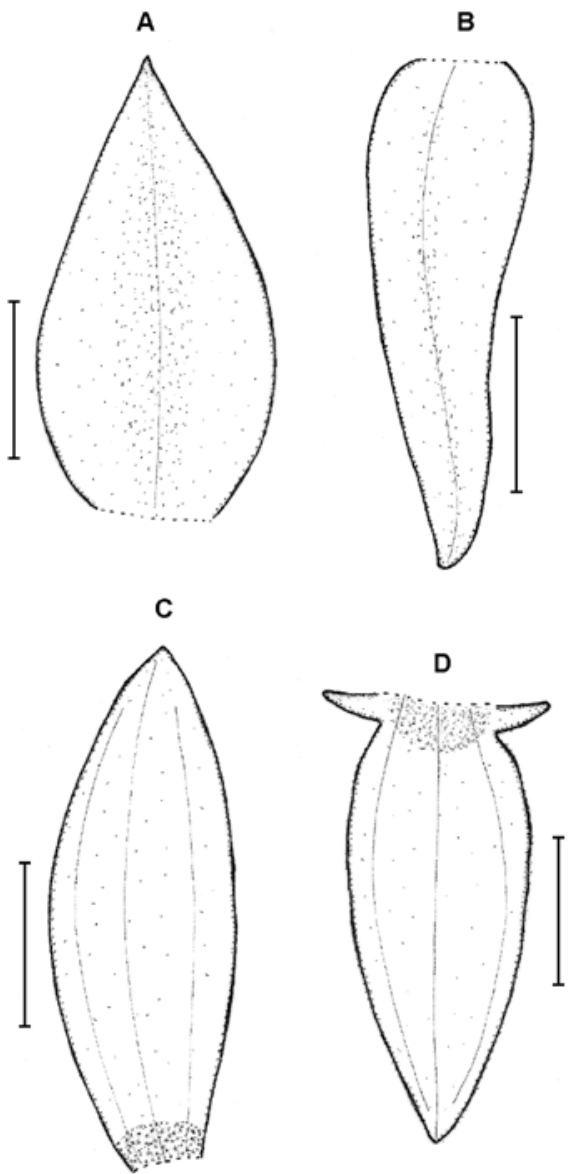

Fig. 1. Stellilabium valdiviesoanus Kolan. \& R. Medina Tr., sp. nov. - dissected perianth. A - dorsal sepal, B - petal, C lateral sepal, D - lip. Scale bars $=1 \mathrm{~mm}$. Drawn from holotype.

Colombia in the valley of the Sibundoy River. It was found growing epiphytically in recovered forest at ca $2150 \mathrm{~m}$ a.s.1. Flowering in March and April.

TAXONOMic notes. This species resembles S. pogonostalix (Rchb. f.) Garay \& Dunst. and most resembles $S$. alticola. In both of those species the lip is oblong to oblong-ovate, widest near the apical third, equally wide along the basal part (vs lip ovate widest near the middle and narrowing below to the base as well as up to the apex). From the first species it also differs by its successive inflorescence (vs flowers produced simultaneously) and minutely ciliate margins of the lip (vs margins 

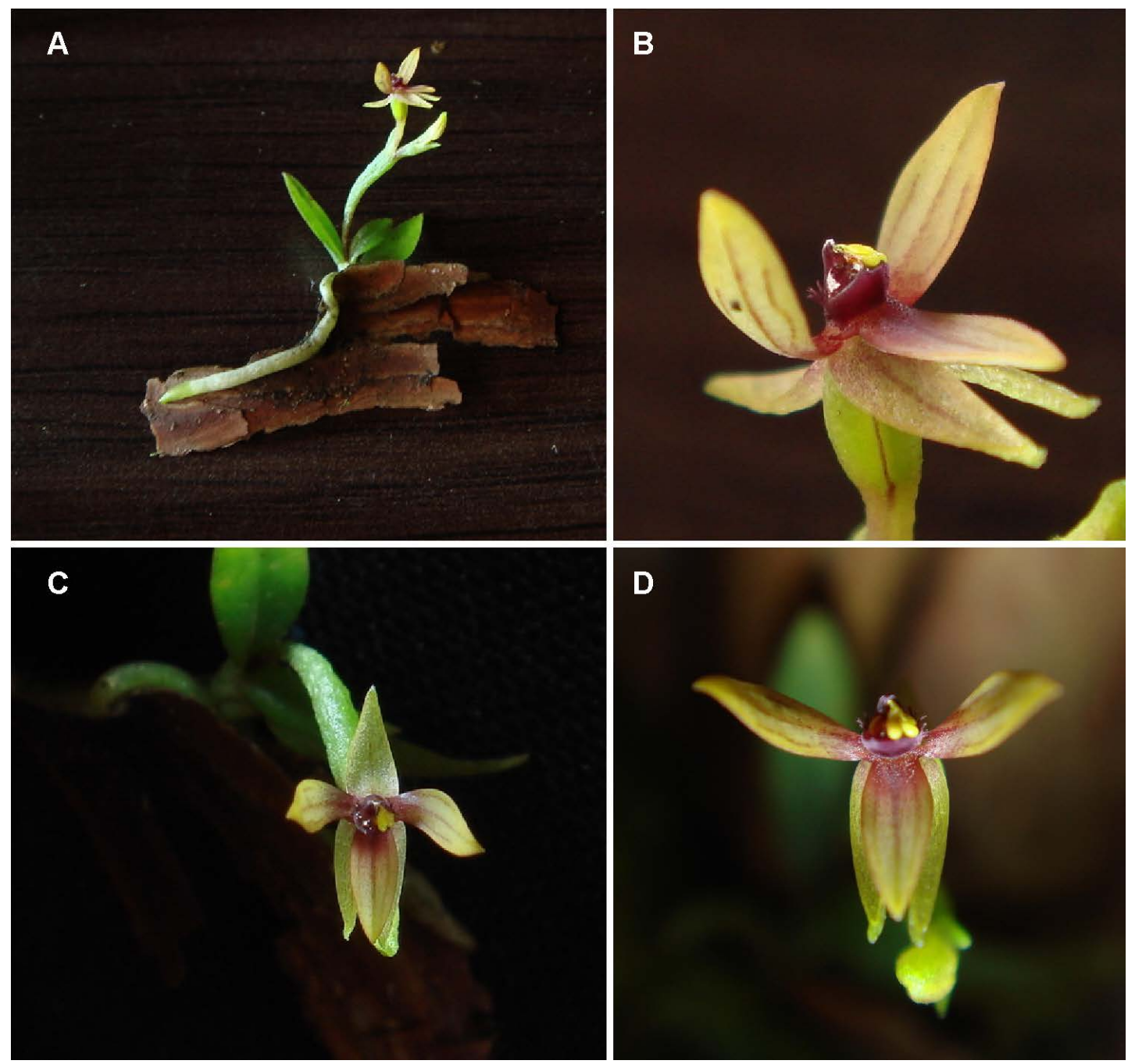

Fig. 2. Stellilabium valdiviesoanus Kolan. \& R. Medina Tr., sp. nov. A - plant habit, B-D - various views of flower. Photo R. Medina.

hispid). Another similar species is the Costa Rican S. bullpenense J. T. Atwood, which is a much taller plant (up to $10 \mathrm{~cm}$ ) with ciliate petals and the gynostemium very densely covered dorsally with branched bristles. Moreover, in this species the lip is widest in the apical third.

\section{Key to THE COLOMBIAN SPECIES of STELLILABIUM}

1. Gynostemium glabrous .

S. hirtzii Dodson

1. Gynostemium with tufts of hairs
2. Lip distinctly and abruptly narrowing in apical part ...... S. microglossum (Schltr.) Dodson

2. Lip gradually narrowing towards apex .... 3

3. Petals broadly elliptic ............. 4 3. Petals lanceolate to oblanceolate ......... 5

4. Lip broadest near base, narrowing towards apex. . S. morganiae Dodson

4. Lip narrowing in apical third, \pm equally broad towards basal $2 / 3 \ldots \ldots \ldots \ldots \ldots \ldots \ldots$ $\ldots \ldots \ldots \ldots$ S. lankesteri (Ames) Dressler

5. Lip entire, lacking appendices at base ........ $\ldots \ldots \ldots \ldots$. . atropupureum P. Ortiz 
5. Lip 3-lobed or with distinct appendices at base. . 6 6. Flowers produced singly in succession . . . . 7 6. Flowers produced simultaneously ...........

S. andinum (L. O. Williams) Garay \& Dunsterv.

7. Lip oblong to oblong-ovate, widest well below middle ......... S. alticola Dodson \& Escobar

7. Lip ovate . . . . . . . . . . . . . . . . . . . . . . . . S. valdiviesoanus Kolan. \& R. Medina Tr.

ACKNOWLEDGEMENTS. We thank the anonymous reviewer for constructive comments on the manuscript. The research described here was supported by the Faculty of Biology of the University of Gdańsk, and by the Foundation for Polish Science (Fundacja na rzecz Nauki Polskiej, FNP).

\section{REFERENCES}

Ames O. \& Schweinfurth C. 1925. New or noteworthy species of Orchids from the American tropics. Sched. Orchid. 8: $1-91$.

Bernal R., Gradstein S. R. \& Celis M. 2015. Catálogo de plantas y líquenes de Colombia. Instituto de Ciencias Naturales, Universidad Nacional de Colombia, Bogotá. http:// catalogoplantascolombia.unal.edu.co

BraAs L. A. \& LüCKel E. 1982a. Gattungen mit Bestimmungsschluessel der Telipogon-Verwandtschaft (subtribus Telipogoninae Schltr.): Telipogon H.B.K., Trichoceros H.B.K., Stellilabium Schltr., Dipterostele Schltr., Darwiniella Brass \& Lueckel. Orchidee (Hamburg) 33: 170.

Braas L. A. \& Lückel E. 1982b. Darwiniella, eine neue Gattung der Subtribus Telipogoninae Schltr. Orchidee (Hamburg) 33: 167.

DALSTRÖM S. \& Ruíz PÉREz S. 2012. Three new small-flowered Cyrtochilum species (Orchidaceae: Oncidiinae) from Co- lombia and Peru, and one new combination. Lankesteriana 12: $147-153$.

Dodson C. H. 2004. Native Ecuadorian Orchids. 5: Rodriguezia-Zygosepalum. Dodson Publishing, Sarasota, Florida.

DrESSLER R. L. 1999. A reconsideration of Stellilabium and Dipterostele. Harvard Pap. Bot. 4: 469-473.

Dressler R. L. 2003. Orchidaceae. In: B. E. Hammel, M. H. Grayum, C. Herrera \& N. Zamora (eds), Manual de Plantas de Costa Rica. 3: Monocotiledóneas (Orchidaceae-Zingiberaceae). Monocotiledóneas (Orchidaceae-Zingiberaceae). Monogr. Syst. Bot. Missouri Bot. Gard. 93: 1-595.

Garay L. A. \& Romero-González G. A. 1998. Schedulae Orchidium. Harvard Pap. Bot. 3: 53-62.

Hills H. G. \& Weber M. H. 2012. Dressleria morenoi (Orchidaceae, Catasetinae): A new species from Colombia. Phytoneuron 103: 1-5.

Kolanowska M. \& SzlachetKo D. L. 2014 A New Species of Hirtzia (Orchidaceae) from Colombia. Syst. Bot. 39: 36-40.

Ortiz Valdivieso P. \& Uribe Vélez C. 2007. Galería de Orquideas de Colombia (CD edition). Asociación Bogotana de Orquideología, Bogotá.

Pérez Escobar O. A., Parra-Sánchez E., Kolanowska M. \& Ortiz VAldivieso P. 2011. Primer reporte de Telipogon lankesteri Ames (Orchidaceae) para Colombia. Orquideología 28(1): 36-40.

SChLechter R. 1915. Die Orchideen III. Aufzaehlung und Beschreibung der Gattungen und der hauptsaechlichsten Arten, Gruppe 60: Telipogoninae. P. Parey, Berlin.

Schlechter R. 1921. Die Orchideenfloren der Suedamerikanischen Kordillerenstaaten, III. Ecuador. Repert. Spec. Nov. Regni Veg. Beih. 8: 1-172.

Williams N. H., Whitten W. M. \& Dressler R. L. 2005. Molecular systematics of Telipogon (Orchidaceae: Oncidiinae) and its allies: nuclear and plastid DNA sequence data. Lankesteriana 5: 163-184. 